\title{
CASCADED CELL STRING CURRENT DIVERTER FOR IMPROVEMENT OF PHOTOVOLTAIC SOLAR ARRAY UNDER PARTIAL SHADING PROBLEMS
}

\author{
Cláudio H. G. dos Santos ${ }^{1}$, Pedro F. Donoso-Garcia ${ }^{2}$, Seleme I. Seleme Jr ${ }^{2}$, André P. Magalhães ${ }^{1}$ \\ ${ }^{1}$ Federal Center of Technological Education of Minas Gerais - CEFET-MG, ${ }^{1}$ Divinópolis - MG, Brazil \\ ${ }^{2}$ Federal University of Minas Gerais - UFMG, Belo Horizonte - MG, Brazil \\ e-mail: claudiosantos@div.cefetmg.br, pedro@cpdee.ufmg.br, seleme@cpdee.ufmg.br, andrepalharesmagalhaes@gmail.com
}

\begin{abstract}
Partial shading has shown to be a common efficiency issue for photovoltaic arrays installations, whether for islanded or grid-tied systems. Current diverter appears as reasonable solution, but with the increasing of string order, the currents deviated difficult the sizing of inductors. Also, in this type of converter, a multilevel synchronized gate-driver is needed. In this work, an independently cell string current diverter is proposed. This configuration is based in the NonDissipative String Current Diverter, however, its inductors current achieve low values during partial shading, and does not need synchronism of its gatedrivers. Also, this configuration facilitates one local Maximum Power Point Tracking for each module, and enables the enhancement of efficiency with simple implementation. The simulation and experimental results are presented to give support to the theoretical development.
\end{abstract}

Keywords - Current Diverter, Efficiency Enhancement, Partial Shading, PV Modules, String Converter.

\section{INTRODUCTION}

In the last years, the research on solar photovoltaic generation has grown in many directions, most concentrating in global efficiency improvement. Usually, involves a microgrid consisting of a photovoltaic (PV) array, wind generation, a bank of batteries, charge controllers, central inverters, microinverters or string inverters that together configure a distributed generation system [1], [2]. The microgrid, whether islanded or grid-tied, has assumed many roles and applications as battery chargers and electric vehicles [3], [4], power quality regulation [1], for uninterruptible power system (UPS) [5] and many others. In fact, many works concentrate in the control of the grid, others in the application of the generated energy, and others in the efficiency improvement. There are many facts that affect the efficiency of microgrid, and many solutions. A problem that has been constantly discussed is the effect of partial shading of PV array.

As known, a string of panels is a series connection of modules for a higher voltage level establishment [6]. The problem of partial shading has been solved through changing the type power extraction. As shown in [6], there are different types of PV configuration, like: the central inverter, the string inverter, the multi-string inverter, microinverter

Manuscript received 13/02/2015; revised 28/04/2015; accepted for publication $05 / 09 / 2015$, by recommendation of the Regular Section Editor Cassiano Rech. and the microconverter. Basically, microinverter and microconverter are the most efficient solution under partial shading, but not efficient as the string and multi-string inverter when the array is fully insolated [7]. Thus, to improve the efficiency during shading without causing efficiency decrease under normal conditions, it is worthwhile the investment in new ways to make string converters or inverters to deliver as much power as the microconverter or microinverter array under partial shading.

An interesting approach is the diverter topology for a string. When a series of panels in a string is shaded, all the panels tend to have the current limited by the shaded one. In many cases, if a single module is shaded, the other modules force their current through the shaded module, causing excessive power dissipation in this module, and the fail or shorten of its lifetime [8]. As a common known solution, diodes are connected in parallel with each module, and the current can be deviated by diodes, as illustrated in Figure 1 (a). Under partial shading, the diodes disable the shaded panels to enable fully insolated panels to deliver their maximum power, as shown in the red curve of Figure 1 (c) and (d). The problem is that the $\mathrm{P} \times \mathrm{V}$ characteristic curve

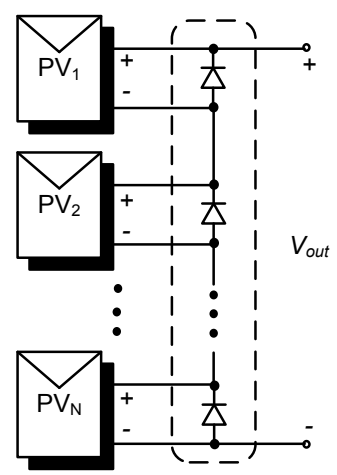

(a)

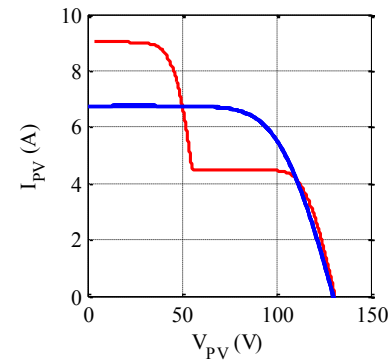

(c)

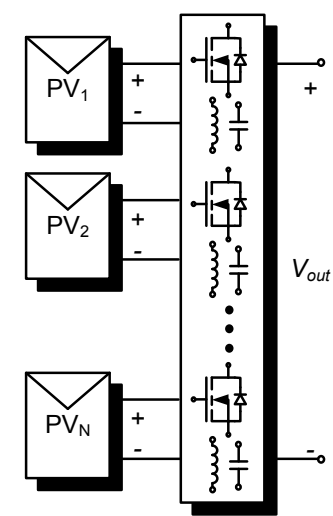

(b)

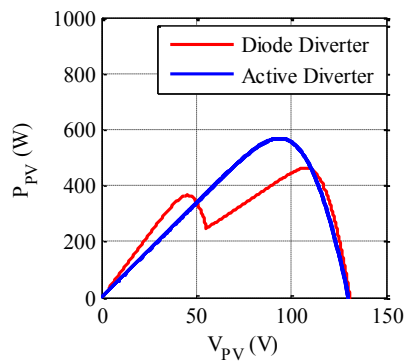

(d)
Fig. 1. Basic types of current deviation: (a) Diode diverter; (b) Switched diverter; (c) $\mathrm{I} \times \mathrm{V}$ curve of diverter strings; (d) $\mathrm{P} \times \mathrm{V}$ curve of diverter strings. 


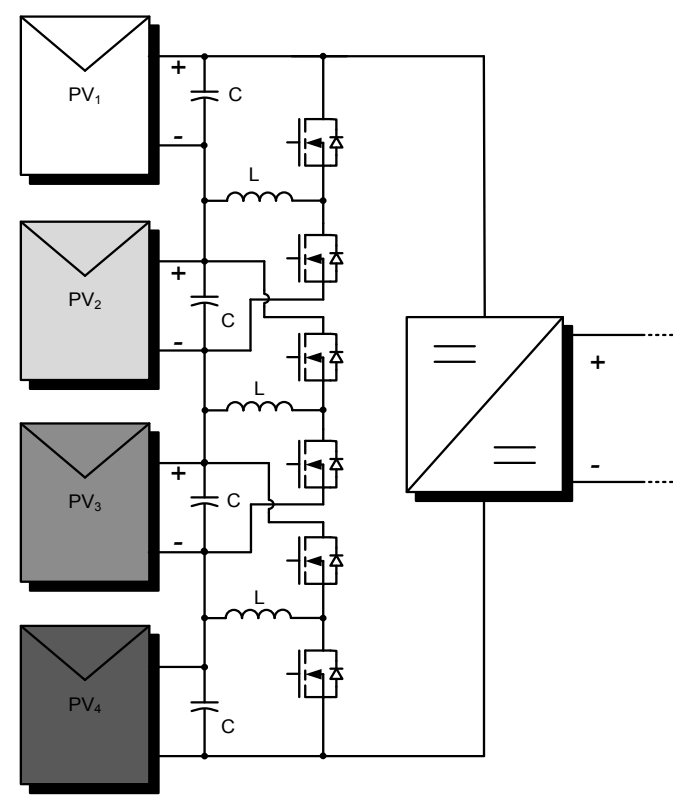

Fig. 2. Classical structure of Non-Dissipative String Current Diverter [11], [12].

gains more than one maximum. In some works, a maximum power point tracker (MPPT) capable to track the global maximum is implemented [9]. However, even the global maximum is considerably smaller than all modules maximum power points (MPP) summed. In others works, a multi-input converter is used to parallel all the modules [10]. If a switched diverter is used, as illustrated in Figure 1 (b), instead of diode, the result is that all panels deliver different currents, resulting in better characteristic, with only one maximum in the $\mathrm{P} \times \mathrm{V}$ curve, as shown Figure 1 (c) and (d), as the blue curve.

In [11], [12], a non dissipative switched diverter is introduced. The current deviation is done by voltage equalization, enabling the module to deliver different currents, but having the same voltage. This diverter is called Non-Dissipative String Current Diverter (NDSCD), here illustrated in Figure 2. In this figure, a circuit is shown for a series of four panels, but it can be expanded to a higher order string. Each half bridge in the circuit is switched with a square wave (50\% duty-cycle), and each bridge switches $180^{\circ}$ phase-shifted from the previous one. However, this circuit presents a problem when is under partial shading. As the string order increases, the inductors currents in the center also increases, which difficult the sizing of these inductors. In this paper, a new topology of current diverter based on the NDSCD is proposed, here shown in Figure 3. It has the advantage that the inductors currents do not increase with the array order, which facilitates their design. Also, as will be shown, the new topology works with separated deviation circuits, called diverter cells, which operate independently of each other, and do not need synchronism. Since the new topology consists of independent circuits, each deviation cell may have its own gate-driver oscillator, and also its own local MPPT. This fact enables each panel to work, not only with different currents, but also with different voltages. Therefore, each panel may deliver its maximum power under

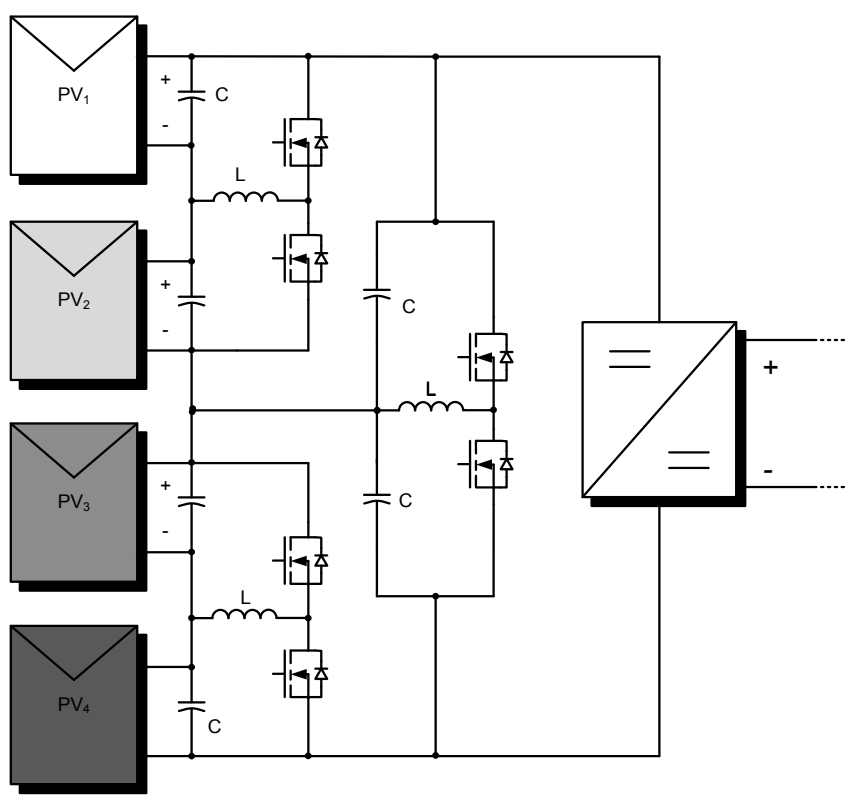

Fig. 3. Proposed Topology of Non-Dissipative String Current Diverter.

different conditions of solar irradiation and temperature, and an efficiency improvement is achieved, with not much cost.

This paper is organized as following. After a brief introduction, a NDSCD analysis is discussed in the second section, in which its operation principles are detailed, and issues of this topology are pointed out through simulation results. In Section III, the proposed topology is presented, and its main advantages are discussed. Also, the principle of deviations cells is presented. In Section IV, simulation results are shown. The first series of results points out the advantage of diverter application, and its gain in power. In following, the inductor currents comparisons for both topologies are shown, in which the proposed topology presents an advantage. Simulation results using a local MPPT for each deviation cell are shown, and an efficiency enhancement is obtained. Also, its application for strings with different panels is presented. Experimental results shows the operation for four panels string which corroborates with the theoretical development. In final section, conclusions are made.

\section{NDSCD ANALYSIS AND ISSUES}

The basic principle of the NDSCD is the voltage equalization of PV modules. By switching the half-bridge with $50 \%$ duty-cycle, with an adequate frequency, it enables each module in the string to deliver a different current from the others. However, they will operate at the same voltage. Since the open circuit voltage $\left(\mathrm{V}_{\mathrm{OC}}\right)$ and the MPP (Maximum Power Point) voltage $\left(\mathrm{V}_{\mathrm{MPP}}\right)$ do not vary drastically with temperature, all modules will operate close to the MPP at the same voltage. In the next sub-sections, some important features and issues of the NDSCD are discussed.

\section{A. Basic Principles of Operation}

The voltage equalization is realized through a half-bridge that switches a square wave in an inductor which is connected in the neutral point of this same bridge and between two panels. In each panel a capacitor is connected, 
and thus, if the capacitors have their voltage equalized, the PV modules will also have the same voltage.

In Figure 4 waveforms during the switching intervals of a NDSCD for a two modules string are shown. It can be observed that the inductor current has triangular waveform with a DC component. This DC component corresponds to the current deviated, which is equal to the current mismatch between the modules. The sign of the DC current depends on which panel is shaded. The amplitude of the triangular component depends of the voltage of both panels. This voltage is considered continuous, due to capacitors and high switching frequency.

This circuit involving only two panels is here called diverter cell. In the configuration shown in Figure 2, the classical NDSCD corresponds to a series of interleaved connections of various diverter cells. In this work, these cells are set in a different manner, as shown Figure 3. The difference is that, instead of connecting in an interleaving

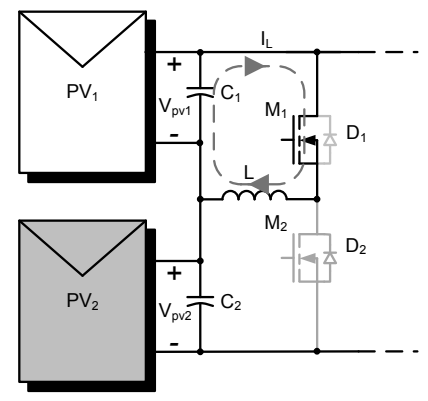

(a)

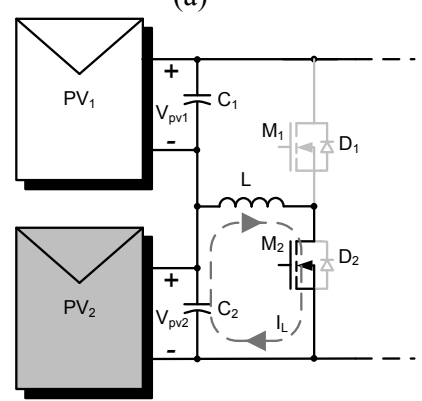

(c)

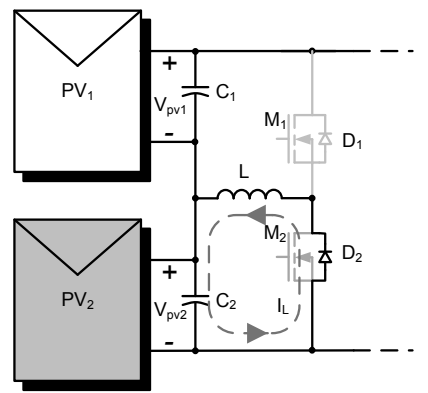

(b)

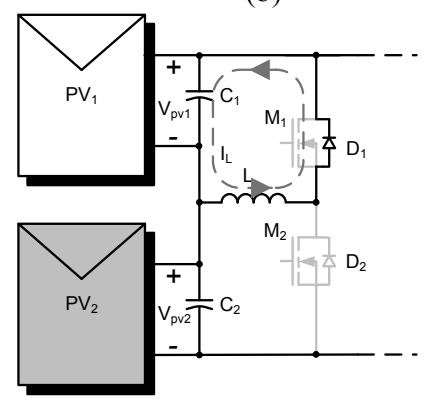

(d)

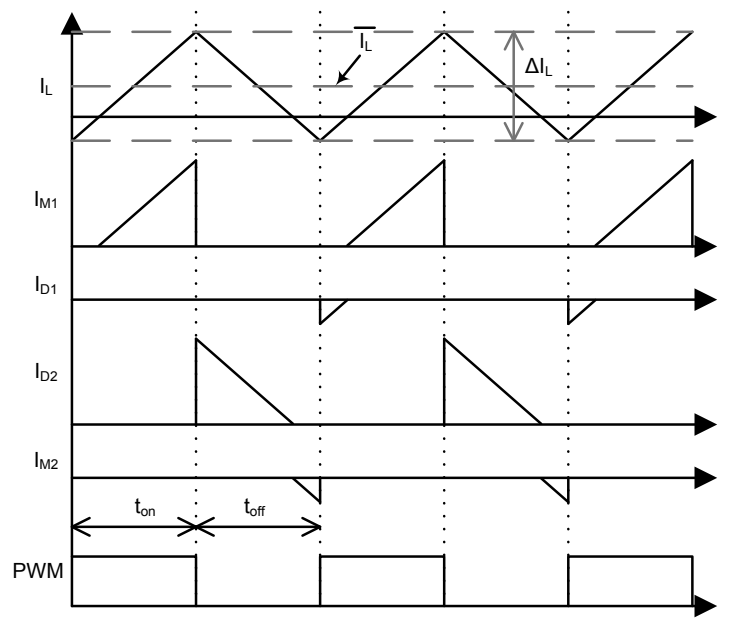

(e)

Fig. 4. Two panels NDSCD switching intervals: (a) $M_{1}$ conducting; (b) $\mathrm{D}_{2}$ on freewheel; (c) $\mathrm{M}_{2}$ conducting; (d) $\mathrm{D}_{1}$ on freewheel; (e) illustration of inductor current in each interval. way, each pair of panels has a diverter cell. Then, each pair of diverter cells is connected through another diverter cell, and so on.

\section{B. Order Increase and PV Array Problems}

Simulation studies had shown that the NDSCD central inductors current DC component reaches higher values when the string order is increased. This phenomenon can be explained as a diverted current accumulation from one pair of panels to the next. It is most critical when the first half of the string is shaded in sequence, while the other half is fully insolated. This situation is quite probable to happen, due to large structure like trees, buildings and clouds.

In Figure 5, the higher inductor current as a function of the string order is shown for both topologies. As can be observed, in the case of the classical NDSCD, as the order increases, the current also increases. However, for the new topology the inductor current does not increase with the array order. This is an important advantage since lower inductors currents lead to lower magnetic flux intensity. This fact facilitates the design of the diverter inductors, which are expensive elements of this circuit.

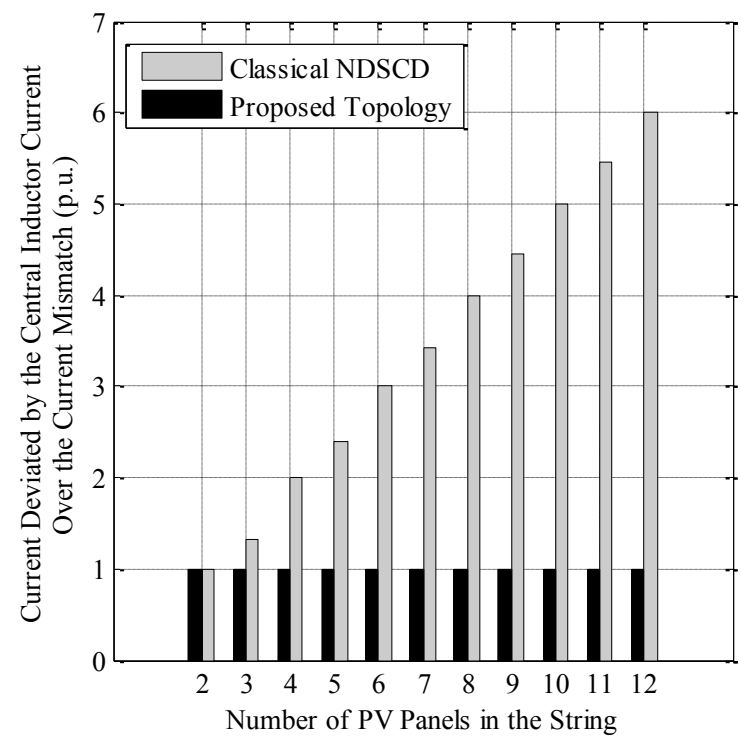

Fig. 5. Increasing current deviated by the central inductor due to increasing order array.

\section{PROPOSED TOPOLOGY}

As mentioned before, in Figure 3 the new proposed topology for the NDSCD is shown. The main difference of this approach is that it uses diverter cells operating in cascade instead of interleaved. Thus, the new topology is named as Cascade Cell String Current Diverter (CCSCD). Each panel is connected to a diverter cell, and each pair of diverter cells is connected to another external diverter. This configuration brings many advantages, besides the inductor limitation.

Two control possibilities of CCSCD are implemented. First, with $50 \%$ duty-cycle operation, the voltage equalization of all modules is applied, as illustrated Figure 6 (a). In second, by measuring the current and voltage output of the diverter cell, a local MPPT can be implemented, as illustrated in Figure 6 (b). This fact allows to search and 
reach each module individual MPP, by varying the voltage of each panel instead of equalizing. Thus the MPPT actuates in the duty-cycle of the diverter cell, and enhances the array efficiency when the modules are under different solar irradiation and temperature. Since the shaded panels are less heated by the solar light, it is expected that their $\mathrm{V}_{\mathrm{MPP}}$ to be greater than the fully insolated ones, due to small temperature differences. However, even arrays without any shading may show different MPP. In fact, even panels from the same manufacturer may show differences in operation under the same conditions. Whether installed in a single fixed plane, or in different planes on a building, certain panels may have different temperatures. Further when some panels are more ventilated then other.

One cannot fail to mention that the increase of array efficiency with local MPPT in the diverter cells is expected to be small, since modules rarely have big temperature differences. Both NDSCD and CCSCD are suitable to implement an MPPT to vary the voltage of each panel. However, in the CCSCD, implementation of local MPPT would worth it, taking into account that the diverter cells would not need communication, synchronism, and can operate independently. Thus, although the efficiency enhancement is expected to be small, an easy and low cost circuit can be implemented. In this work, the local MPPT is implemented following the $\mathrm{P} \& \mathrm{O}$ algorithm principles.

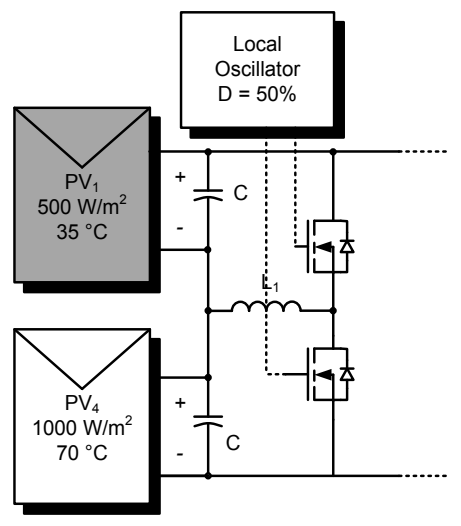

(a)

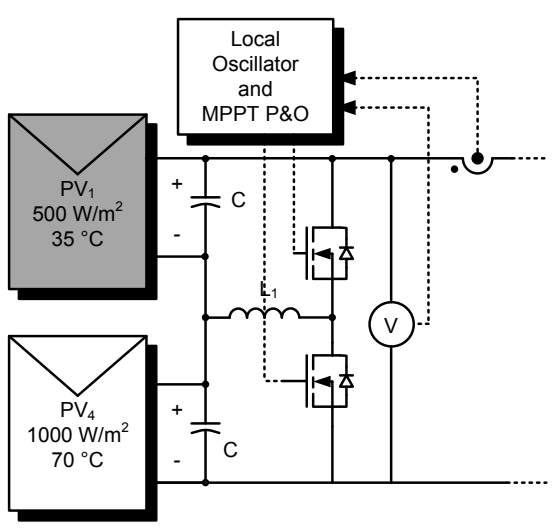

(b)

Fig. 6. Diverter cell with local oscillator: (a) fixed 50\% duty-cycle; (b) with local MPPT to control the voltage of each panel.

\section{SIMULATION RESULTS}

In this section, simulation results carried in $\operatorname{PSIM}^{\circledR}$ are presented. As a MPPT string converter, a Four Switch BuckBoost (FSBB) converter was used, and as discussed in many papers, it consists of a simple bidirectional bridge suitable for battery chargers in PV systems, and it can operate as a Buck or Boost depending on the requirements [13] - [16]. In Figure 7, a more complete scheme of the simulations is illustrated, in which the FSBB is the string converter of a PV array with mismatch deviated by the CCSCD. In Table I, the basic parameters of this simulation are presented. The sizing methodology is based on references like [17].

The first results are to explain the operation and advantages of both diverters. In following, results of a comparison between the NDSCD and the CCSCD are presented. At last, results of the CCSCD with local MPPT algorithm are shown, in which the duty-cycle of each deviation cell is varied individually in a manner to track the individual MPP of each PV module.

TABLE I

Simulation Parameters

\begin{tabular}{|c|c|c|c|}
\hline \multicolumn{4}{|c|}{ PV Array Panels Parameters } \\
\hline $\begin{array}{l}\mathrm{V}_{\mathrm{OC}} \\
\left(25^{\circ} \mathrm{C}\right)\end{array}$ & $\begin{array}{l}\text { Open Circuit } \\
\text { Voltage }\end{array}$ & 37.7 & $\mathrm{~V}$ \\
\hline $\begin{array}{l}\mathrm{I}_{\mathrm{SC}}\left(25^{\circ} \mathrm{C}\right) \\
(1000 \\
\mathrm{W} / \mathrm{m} 2)\end{array}$ & $\begin{array}{l}\text { Short Circuit } \\
\text { Current }\end{array}$ & 8.91 & $\mathrm{~A}$ \\
\hline $\mathrm{V}_{\mathrm{MPP}}$ & $\begin{array}{l}\text { Maximum Power } \\
\text { Voltage }\end{array}$ & 30.3 & $\mathrm{~V}$ \\
\hline $\mathrm{I}_{\mathrm{MPP}}$ & $\begin{array}{l}\text { Maximum Power } \\
\text { Current }\end{array}$ & 8.59 & A \\
\hline $\mathrm{R}_{\mathrm{S}}$ & Series Resistance & 8 & $\mathrm{~m} \Omega$ \\
\hline $\mathrm{R}_{\mathrm{P}}$ & Parallel Resistance & 1 & $\mathrm{k} \Omega$ \\
\hline \multicolumn{4}{|c|}{ CCSCD and NDSCD Parameters } \\
\hline $\mathrm{L}_{1,2 \mathrm{e} 3}$ & Inductance & 446 & $\mu \mathrm{H}$ \\
\hline $\mathrm{C}$ & Capacitance & 20 & $\mu \mathrm{F}$ \\
\hline $\mathrm{f}_{\mathrm{sw} \_ \text {diverter }}$ & $\begin{array}{l}\text { Diverter Switching } \\
\text { Frequency }\end{array}$ & 50 & $\mathrm{kHz}$ \\
\hline \multicolumn{4}{|c|}{$\begin{array}{r}\text { FSBB Parameters } \\
\end{array}$} \\
\hline $\mathrm{L}$ & $\begin{array}{l}\text { Deviator } \\
\text { Inductance }\end{array}$ & 2 & $\mathrm{mH}$ \\
\hline $\mathrm{C}_{\mathrm{i}}$ & Input Capacitance & 188 & $\mu \mathrm{F}$ \\
\hline $\mathrm{C}_{\mathrm{o}}$ & Output Capacitance & 47 & $\mu \mathrm{F}$ \\
\hline $\mathrm{f}_{\mathrm{sw}}$ & $\begin{array}{l}\text { FSBB Switching } \\
\text { Frequency }\end{array}$ & 20 & $\mathrm{kHz}$ \\
\hline $\mathrm{K}_{\mathrm{i}}$ & $\begin{array}{l}\text { Controller Integral } \\
\text { Gain }\end{array}$ & 350 & - \\
\hline$\overline{\mathrm{p}}$ & $\begin{array}{l}\text { Controller } \\
\text { Proportional Gain }\end{array}$ & 0.23 & - \\
\hline
\end{tabular}

A. Diverter Operation with $D=50 \%$ (Voltage Equalization)

In this subtopic, advantages of the switched diverters NDSCD and CCSCD are presented through simulation results. The results of Figures 8 to 10 are equivalent for both topologies, the classical and new topology here proposed.

In Figure 8, the simulation results for irradiance and temperature variation are presented. An abrupt variation occurring after $1 \mathrm{~s}$ of simulation is considered only to evaluate the system before and after the mismatch. In this simulation, the string has two of its four panels shaded, causing most severe mismatch. The insolated modules 


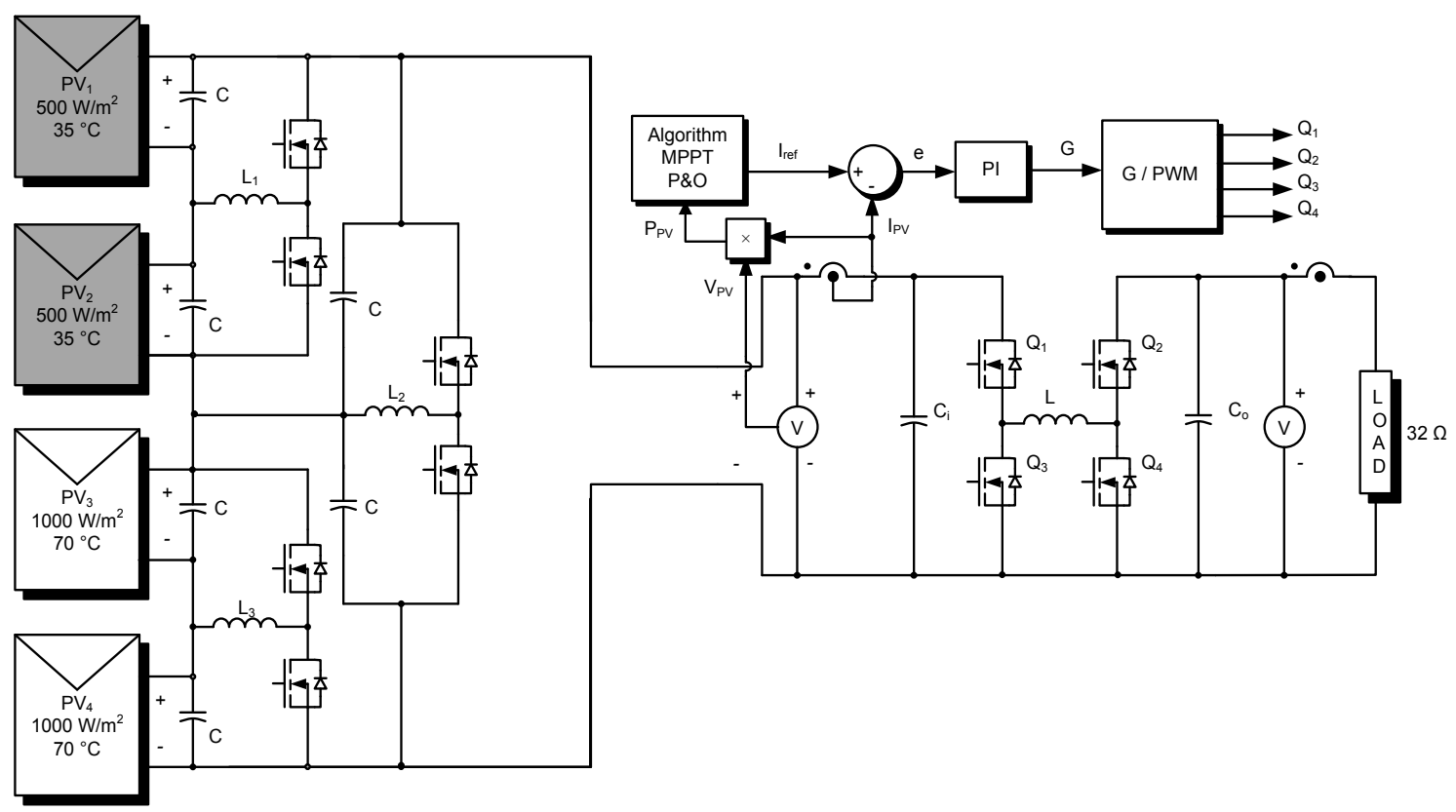

Fig. 7. Simulation of proposed CCSCD with a Four Switch Buck Boost as MPPT String Converter, under partial shading.

are irradiated with $1000 \mathrm{~W} / \mathrm{m}^{2}$ and have temperature of $70^{\circ} \mathrm{C}$, the shaded modules have $500 \mathrm{~W} / \mathrm{m}^{2}$ and $35^{\circ} \mathrm{C}$. In Figure 8 (a) is shown the power of the string for two types of diverter: switched (continuous line) and diode (in traced line). As can be noticed, the switched diverter enables the system to deliver more power, since no fully irradiated PV module is forced to deliver the smaller of shaded ones. In Figure 8 (b) is shown the string output current and the reference from the controller. The current follows the reference indicated by the P\&O MPPT algorithm. When the abrupt shading occurs, the MPPT algorithm resets the reference in search for the new MPP. Before the change the MPP String current is around 8.1 A, and after shading, is around 6.1 A, as shown in Figure 8 (c) and (d). If the diode diverter was used, the string current would be limited to the most shaded module, near $4.05 \mathrm{~A}$.

Figure 9 shows the individual currents of each PV module and the string current before and after the shading, for the same simulation of Figure 8 . As can be noticed, due to the diverter actuation, the string current is the average of the current of all panels in the string. Thus, more power can be extracted from a partially shaded array system.

In Figure 10 (a), each panel voltage is shown during the diverter transient. As can be noticed, voltage equalization enables the array to deliver more power, as shown in Figure 10 (b), since each panel will deliver a different current.

All results presented until now show the advantages of the CCSCD application in a string under partial shading. However, both topologies, the NDSCD and CCSCD, present equivalent performance shown in these results.

\section{B. Advantages of the New Topology}

The first advantage of the proposed circuit is that, under partial shading, the higher inductor currents are not dependent of the string order, and thus the core of the inductor has less probability to be saturated. In Figure 11 is shown the inductors currents of both topologies for the same shading situation of Figures 8 and 9. Figure 11 (a) and (b) show the CCSCD and NDSCD, respectively, for a four panels string, and in Figure 11 (c) and (d) their inductors currents, respectively. As can be observed, in Figure 11 (d) the current of the central inductor $\mathrm{L}_{2}$ achieves the double of the current mismatch between panels, while in the new topology, the current of the inductor $\mathrm{L}_{2}$ achieves only the unitary current mismatch. In other words, the CCSCD inductor will not accumulate deviated currents, as the NDSCD. Therefore, it is clear that both circuits present same performance regarding the efficiency improvement, but, in the proposed circuit, current accumulation is not an issue.

Since the new circuit consists of independent diverter cells, each cell may have its own local oscillator. This fact
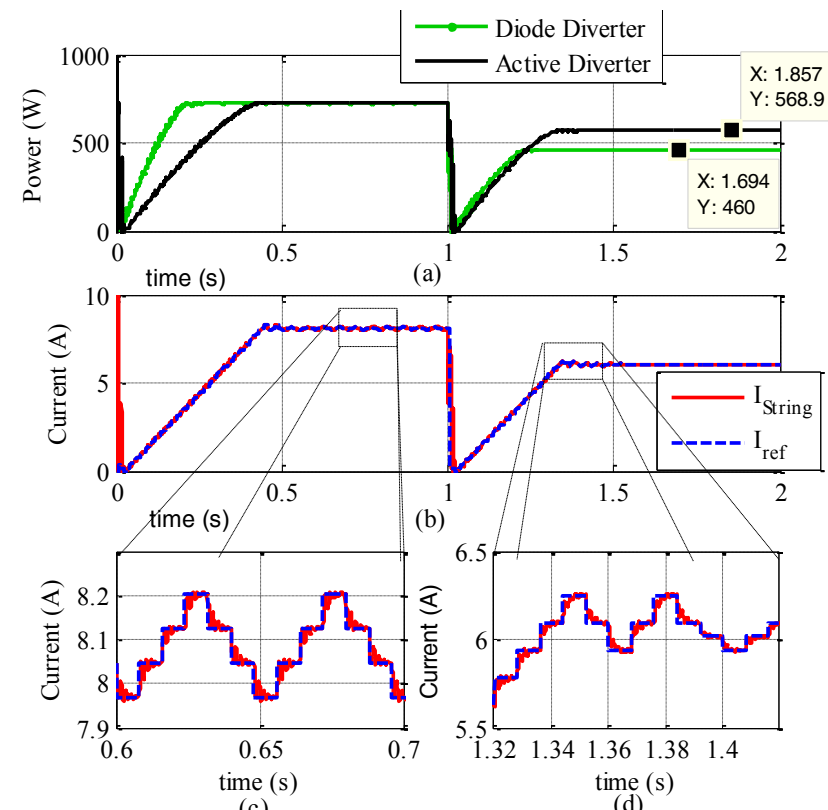

Fig. 8. Operation of MPPT algorithm: (a) power; (b) reference and output current; (c) zoom of current before shading; (d) zoom of current after shading MPPT settled. 


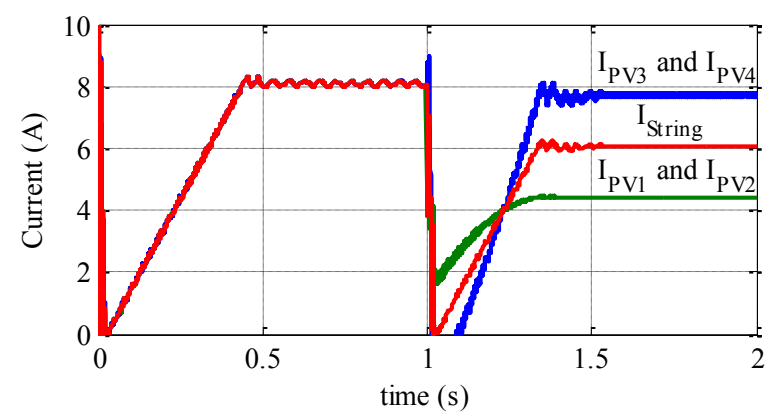

Fig. 9. PV panels and string current output.
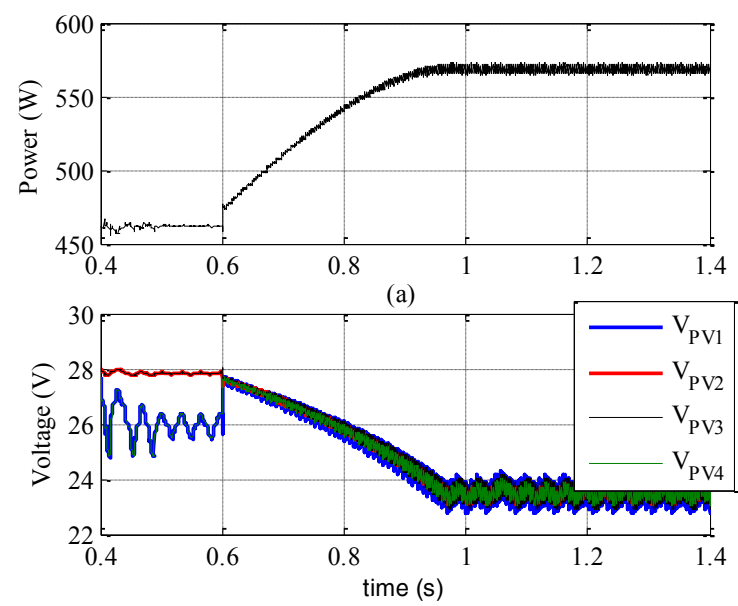

(b)

Fig. 10. Transient peration of NDSCD: (a) String power output; (b) PV Module voltages, during voltage equalization transient.

represents a practical advantage for the experimental implementation, and low cost of driver circuits for the MOSFET bridges. Since the deviation circuits are independent, there is no need of synchronism or communication between them and a local MPPT can be applied only to the diverter cell alone. In other words, a MPPT algorithm that concerns the voltage and current outputs of these two panels involved.

As discussed before, in [11], [12] the circuit driver switches the MOSFETS with fixed 50\% duty cycle. This is because the deviation principle is based on voltage equalization. However if the modules voltages are equalized, it is likely that the panels do not have the same MPP, since their temperature are affected by the irradiation. In other words, the more shaded, the more cold the panel will be, and thus, higher its MPP voltage. Therefore, the string does not deliver its maximum power with all at the same voltage. By varying the duty-cycle, it is possible to find the exact modules voltages to make each module to operate in its MPP. In the next simulation result, this technique is accomplished for the same simulation conditions in Figures 8 and 9.

In Figure 12 is shown a comparison between output power of the CCSCD with fixed duty-cycle in $50 \%$ and the varied duty-cycle due to a Local MPPT. In Figure 12 (b) is shown the Local MPPT duty-cycles for each diverter. The power varies from $569 \mathrm{~W}$ to $588.6 \mathrm{~W}$, corresponding $3.45 \%$ of enhancement. Due to the fast dynamic of the diverter cells, their Local MPPTs do not affect the string converter MPPT. Another advantage of the CCSCD is that the Local MPPTs are easier to implement, since they do not need synchronism or communication with the other cells, measuring only the current and voltage of the two panels involved. In Figure 13 it is shown the $\mathrm{P} \times \mathrm{V}$ curve of the results of Figure 12. As can be noticed, the resulting $\mathrm{P} \times \mathrm{V}$ curve increases in power, and thus, the entire array efficiency.

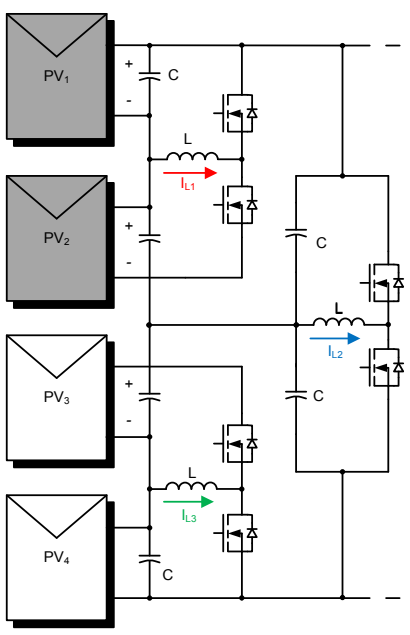

(a)

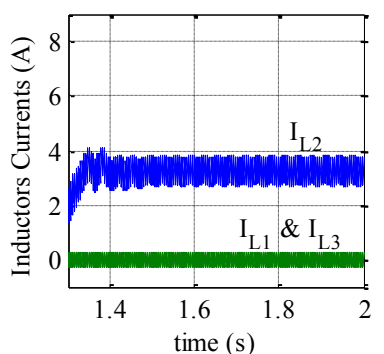

(c)

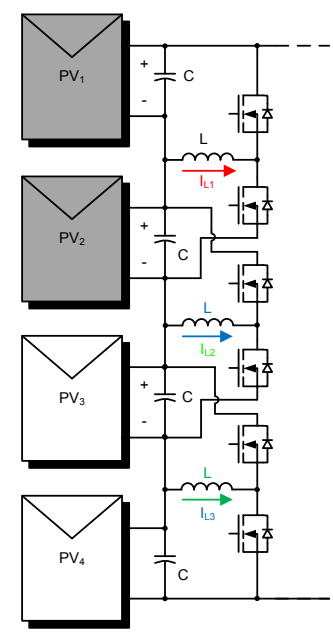

(b)

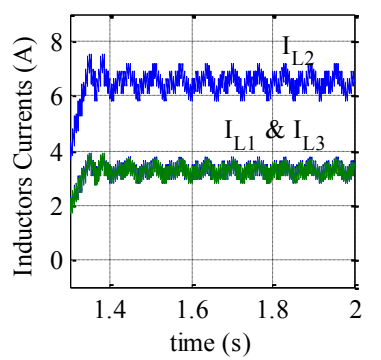

(d)
Fig. 11. Comparison of CCSCD and NDSCD inductor currents of the string under the same shading: (a) CCSCD; (b) NDSCD; (c) CCSCD inductor currents; (d) NDSCD inductor currents.
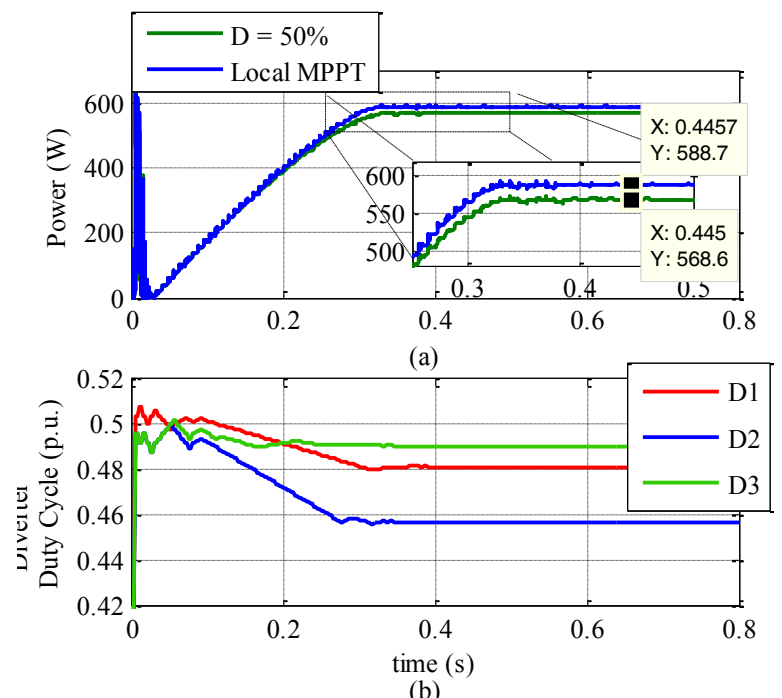

Fig. 12. Comparison between fixed duty-cycle in 50\%, and optimized with an MPPT algorithm: (a) String power output for $50 \%$ fixed duty cycle and local MPPT () Duty cycle of each diverter cell of the CCSCD. 


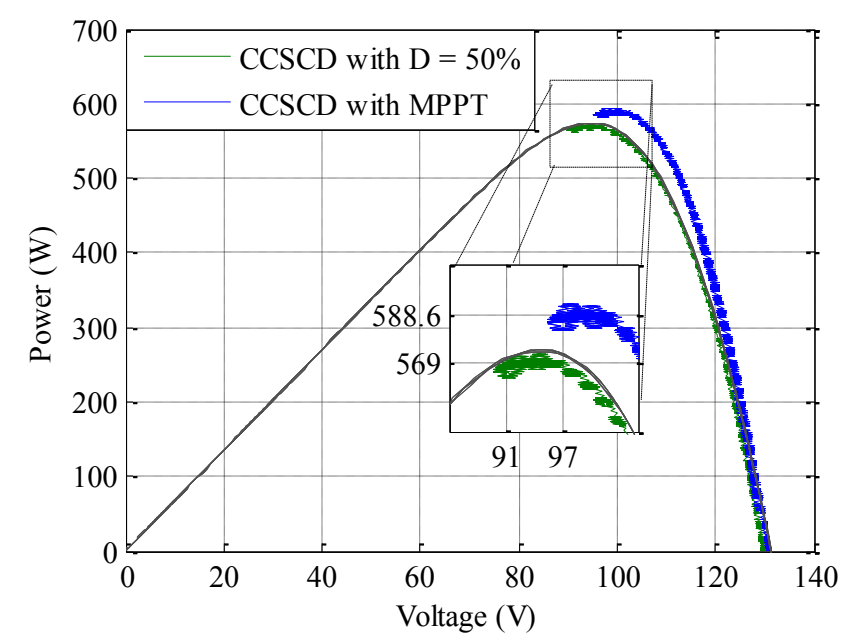

Fig. 13. Comparison between PV characteristic curves of $50 \%$ and MPPT CCSCD.

\section{ADAPTATIONS FOR STRINGS WITH VARIOUS NUMBER OF PANELS}

About the proposed circuit, a main concern that must be clarified is that, as presented, it works only for strings with 2 , 4, 8, 16 number of panels and so on. This fact limits the application for any other string order. However, with small modifications, it is possible to implement it. In Figure 14 (a) and (b) is illustrated the diverter circuit for third order string, for the NDSCD and CCSCD configurations, respectively. As can be observed, the NDSCD is similar to the Figure 2 circuit, and it operates with $50 \%$ duty-cycle.

In Figure 14 (b), the CCSCD adaptation is shown. The first diverter cell with inductor $\mathrm{L}_{1}$, is connected between the panel $\mathrm{PV}_{2}$ and $\mathrm{PV}_{3}$, and operates with $50 \%$ duty-cycles, as expected. The second diverter cell is different. Instead of connected between two panels or pairs of panels, it is connected between the pair of panels $\mathrm{PV}_{2}+\mathrm{PV}_{3}$ and the single panel $\mathrm{PV}_{1}$. However, to equalize the voltages of the $3^{\text {rd }}$ order string it must operate with $66.67 \%(2 / 3)$ duty-cycle, instead of $50 \%$, as illustrated in this figure. This is necessary because, since the single panel has half the pair voltage, it must be connected to the inductor twice as long to equalize its voltage with $\mathrm{PV}_{2}+\mathrm{PV}_{3}$.

In Figure 15, comparisons between the topologies for a 3rd order string are shown through simulation results. In this simulation, the panels $\mathrm{PV}_{1}, \mathrm{PV}_{2}$ and $\mathrm{PV}_{3}$ are illuminated with $330 \mathrm{~W} / \mathrm{m}^{2}, 660 \mathrm{~W} / \mathrm{m}^{2}$ and $1000 \mathrm{~W} / \mathrm{m}^{2}$, respectively. As can be observed, in Figure 15 (a) both circuits allow each panel to deliver a different current. In Figure 15 (b) is shown that both structures equalize the string voltages, as expected. In Figure 15 (c) is shown the inductors currents. As can be noticed, the NDSCD presents higher inductor current levels than the proposed structure.

Another concern that may be questionable is the CCSCD application for strings of order 5, 6, 7 and so on. The idea is to study each case to analyze the best combination of diverter cells to attend the array requirements. For instance, for a 6 order string, an alternative is to implement a diverter cell for two triples, and in each triple, use the circuit of Figure 14 (b), as illustrated in Figure 14 (c).

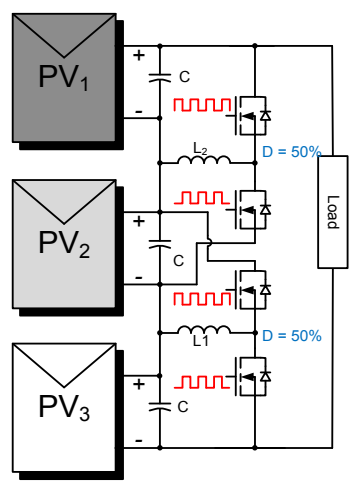

(a)

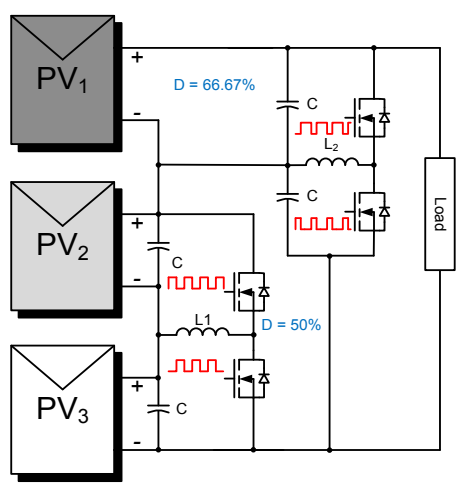

(b)

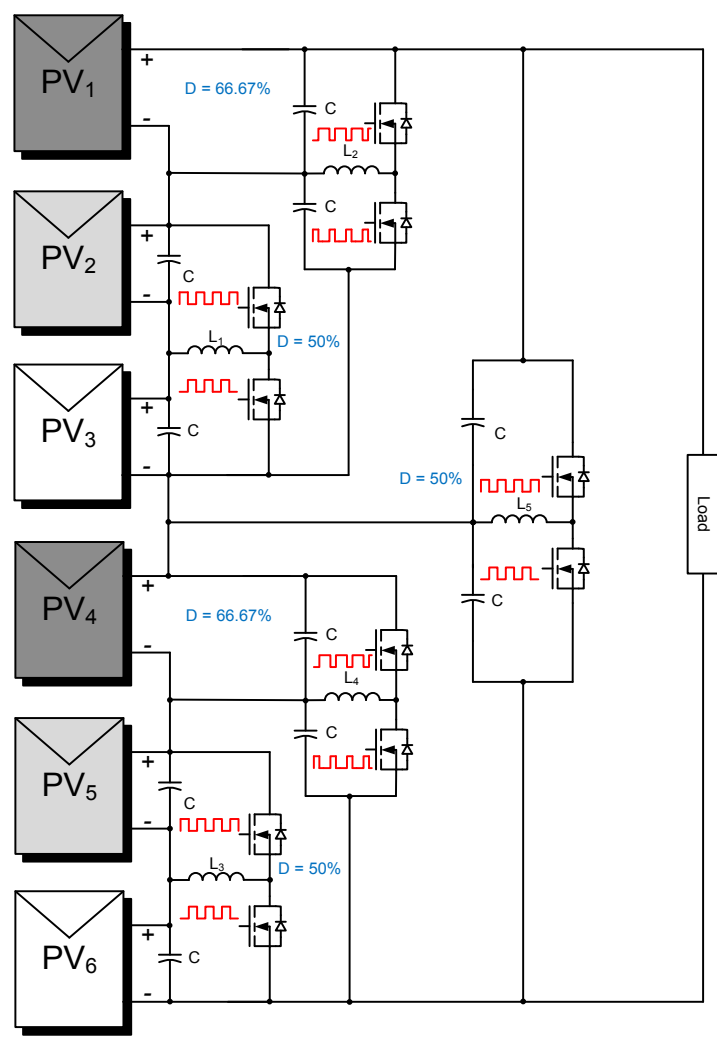

(c)

Fig. 14. Diverter configurations: (a) NDSCD for 3 panels; (b) CCSCD for 3 panels; (c) CCSCD for 6 panels.

As can be noticed, the number of diverters cells used are the same for both the CCSCD and NDSCD topologies, since a six panel string with the NDSCD would require, also, five diverter levels. An alternative is to mix the two topologies, using the NDSCD for the triples, and a diverter cell for the pair of triples. The important is to avoid using an extensive NDSCD and, together, the current accumulation involved.

\section{EXPERIMENTAL RESULTS}

In this section, experimental results are presented to give support for the theoretical development of the proposed circuit. These experiments were realized in the slab of a building in the CEFET-MG, Divinópolis, here shown in Figure 16 (a). According to the simulated circuit, PV panels are numbered as shown in this figure. These panels are 
installed for further solar tracking purposes, and they can be oriented individually in each direction. To implement a situation near the partial shading, the panels were oriented with different angles towards the sun light, as pictured in Figure 16 (b). In Figure 17 is shown the experiment setup with the three diverter cells for the four panels disposed as CCSCD. The diverter cells are numbered following the simulated circuit of Figure 11 (a). As in this simulation, the diverter cell 01 is connected between PV1 and PV2, diverter

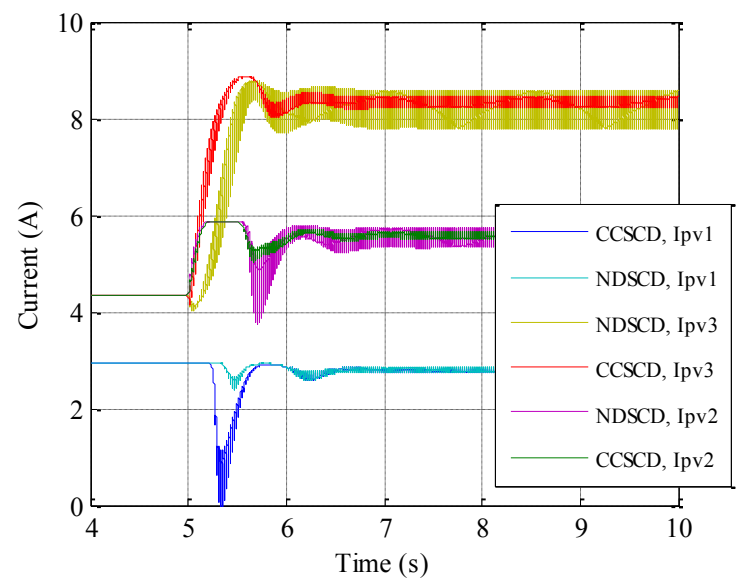

(a)

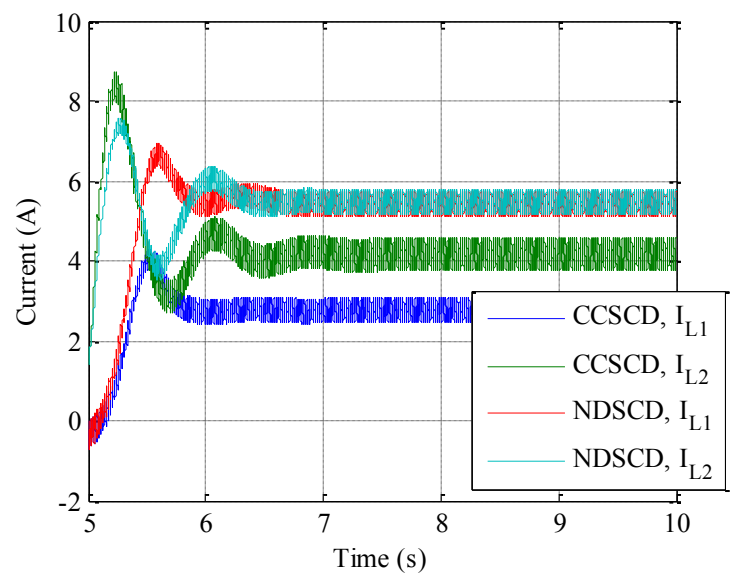

(b)

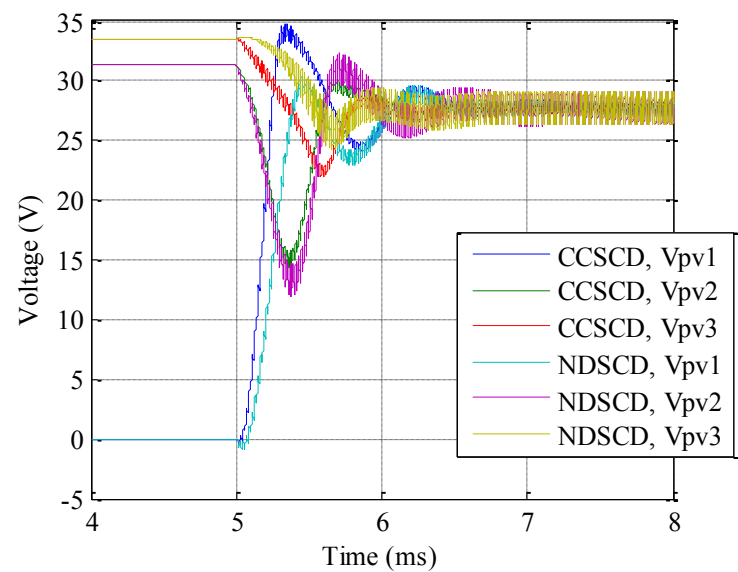

(c)

Fig. 15. NDSCD and CCSCD comparison for 3 panels string: (a) Modules currents; (b) Inductor currents; (c) Modules voltages. cell 03 between PV3 and PV4, and diverter cell 02 between PV1+PV2 and PV3+PV4. As shown in the figures, halleffect current sensors are used to measure the currents, in this case, the ACS714. As a load, a 500W/100 $\Omega$ rheostat is used. The complete schematic of the diverter cells is presented in Figure 18. To implement gate-driver, the bootstrap integrated circuit IR2104 was used. This circuit enables to switch a half-bridge with one PWM signal only. It has a fixed deadtime to avoid the turn on of both MOSFETs at the same time, and the consequent burn. In this figure, two possibilities are shown for MOSFETs and inductors. For diverter cell 01 and 03, MOSFETs IRF540N and $200 \mu \mathrm{H}$ inductor are used. For diverter cell 02 , MOSFETs IRF840N and a $400 \mu \mathrm{H}$ inductor are used. The reason to increase this central diverter inductance is to control the current ripple increase due to the increase of the square wave voltage applied to it.

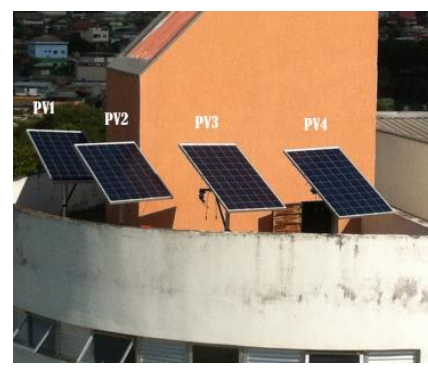

(a)

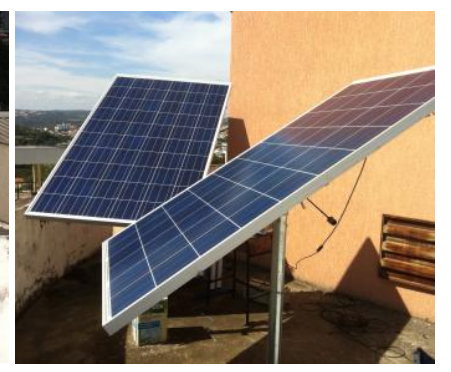

(b)
Fig. 16. Pictures of PV panels installation: (a) Four panels with orientation adjustment; (b) Implementation of near shading conditions with different orientation between panels.

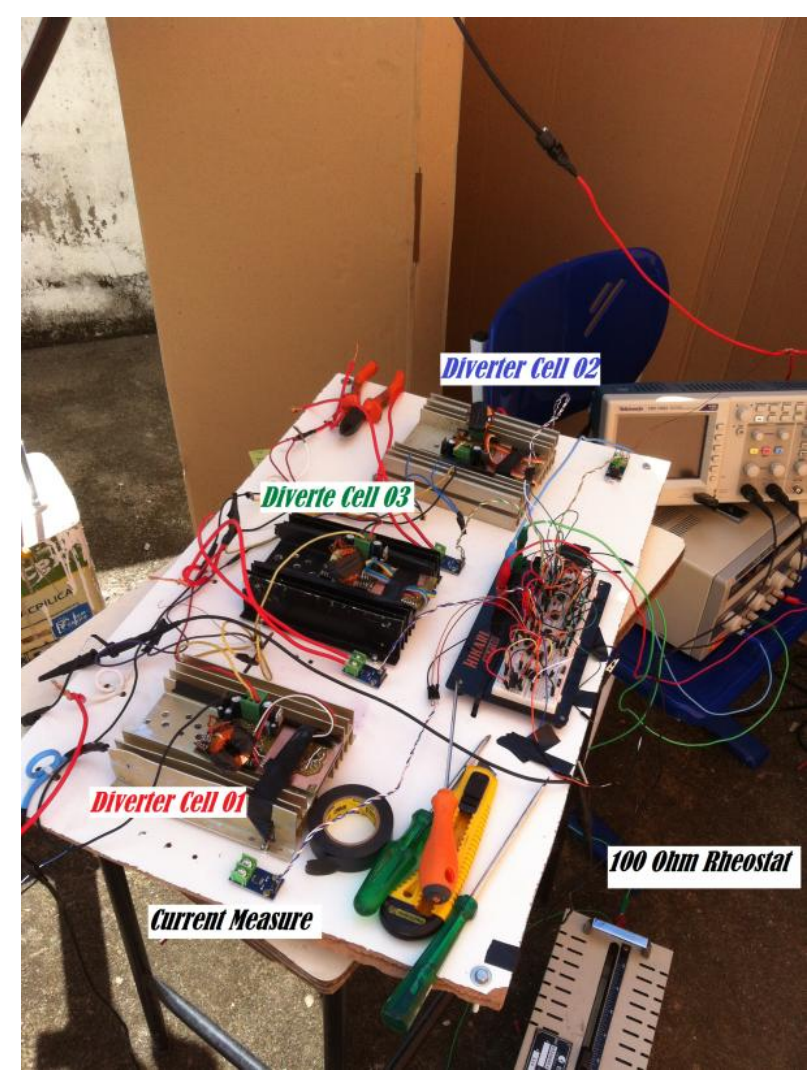

Fig. 17. Picture of the experiment with three diverter cells, configured as CCSCD. 


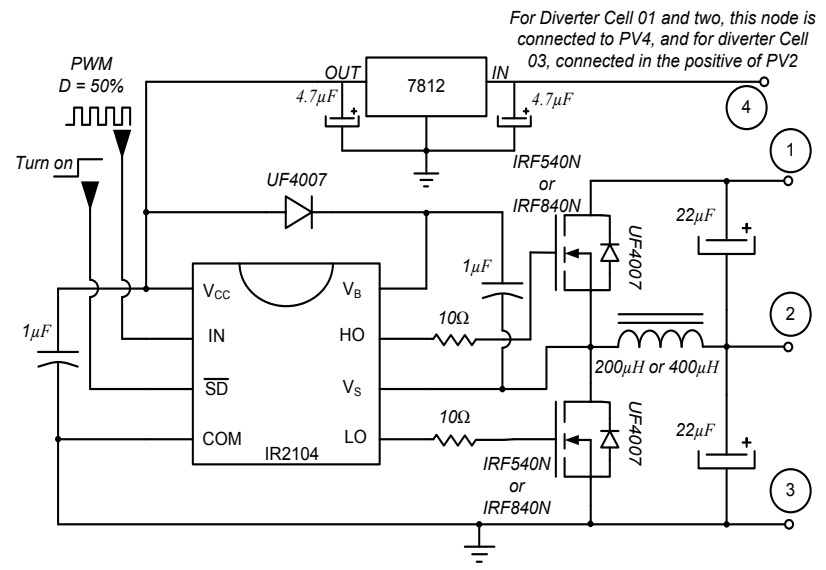

Fig. 18. Diverters Cells schematic.

The PWM switching frequency used in the experiment was around $42 \mathrm{kHz}$ to $44 \mathrm{kHz}$ (not precise due to microcontroller internal oscillator), depending on the diverter cell. The commands come from an individual PIC12F615 microcontroller for each diverter cell. It is important to point out that there is no communication or attempt to synchronize the switching between diverter cells, and their switching frequencies are not exactly the same.

In Figure 19 (a) and (b), the inductor currents of diverter 03 and 01 are shown, respectively. As can be observed, the inductor current in diverter 03 follows a waveform close to the illustrated in Figure 4 (e). This result was obtained with $1 \mathrm{~A}$ of current mismatch between panels PV3 and PV4. The negative DC component of this current is due to the fact that PV4 is more insolated than PV3. Figure 19 (b) shows the current and voltage for diverter cell 02 inductor. In this test, two first panels PV1 and PV2 were oriented away from the sun direction, so they should deliver $4 \mathrm{~A}$ of short circuit, while PV3 and PV4 were oriented towards the sun, so they should deliver $8.3 \mathrm{~A}$ of short circuit current. It can be noticed that the inductor current DC component is compatible to the difference of short circuit current.

In Figure 20 (a), (b) and (c), voltage equalization results are presented, in the following order: (a) PV1 and PV2, (b) Pair PV1+PV2 and Pair PV3 and PV4, (c) a closer look of PV3 and PV4 voltage. As can be observed, after the diverter turn on, the voltage equalization between panels and pair of panels is achieved. However, due to inductance winding resistance, the voltage is not totally equalized, and after the transient, a small difference still remains. This difference is more critical in diverter 02 inductor due to the superior number of turns, and thinner winding wire. In Figure 20 (c), voltage equalization between PV3 and PV4 is shown in a smaller time scale so almost $4 \mathrm{~V}$ ripple can be observed.

In Figure 21 (a), (b), (c) and (d), the currents and voltages of all four panels during the diverter turn on are shown. In this experiment, the first panel is oriented to deliver less current than the rest of the string, as if shaded. In Figure 22 (a) and (b), currents and voltages, respectively, are plotted in the same time window for comparison purposes. Regarding the current, before the diverter turn on, all the panels deliver same current, which is limited to first shaded panel. After the

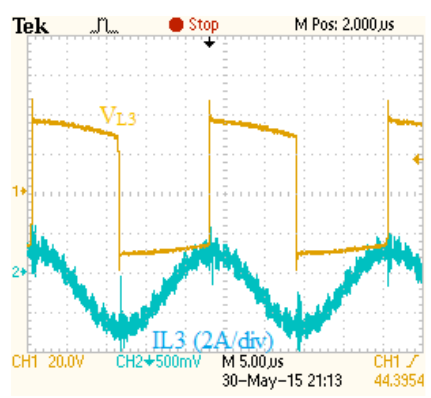

(a)

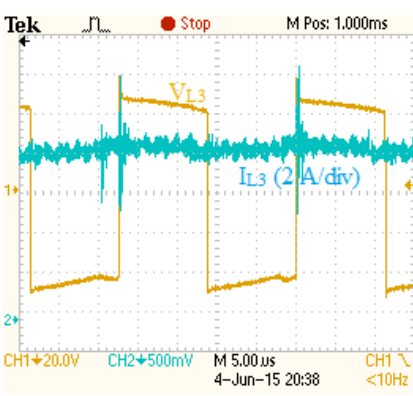

(b)
Fig. 19. Inductor current: a) Inductor current and voltage of the deviation cell 03 ; b) Inductor current and voltage of the deviation cell 02 .

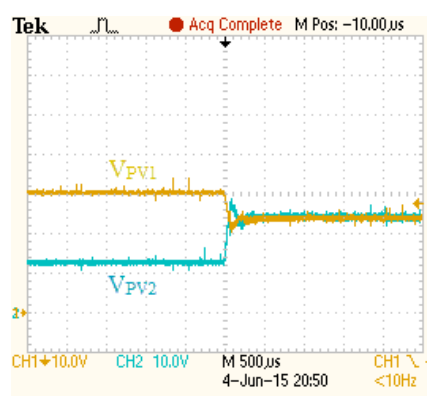

(a)

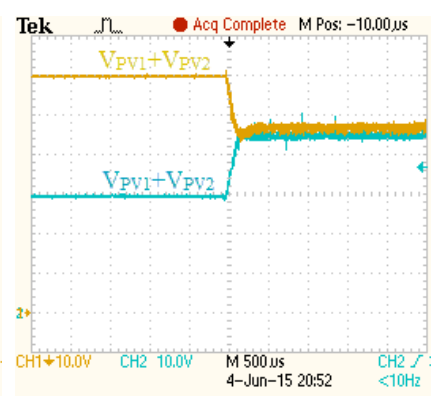

(b)

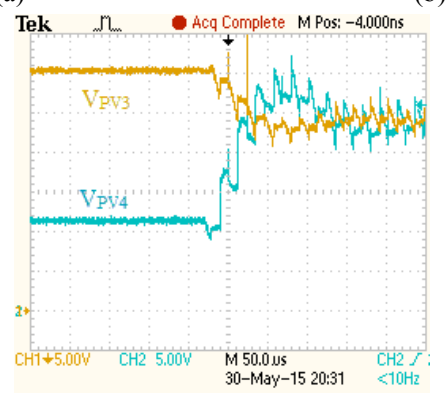

(c)

Fig. 20. Voltage equalization: a) $\mathrm{V}_{\mathrm{PV} 1}$ and $\mathrm{V}_{\mathrm{PV} 2}$; b) $\mathrm{V}_{\mathrm{PV} 1}+\mathrm{V}_{\mathrm{PV} 2}$ and $\left.\mathrm{V}_{\mathrm{PV} 3}+\mathrm{V}_{\mathrm{PV} 4} ; \mathrm{c}\right) \mathrm{V}_{\mathrm{PV} 3}$ and $\mathrm{V}_{\mathrm{PV} 4}$ in a closer look.

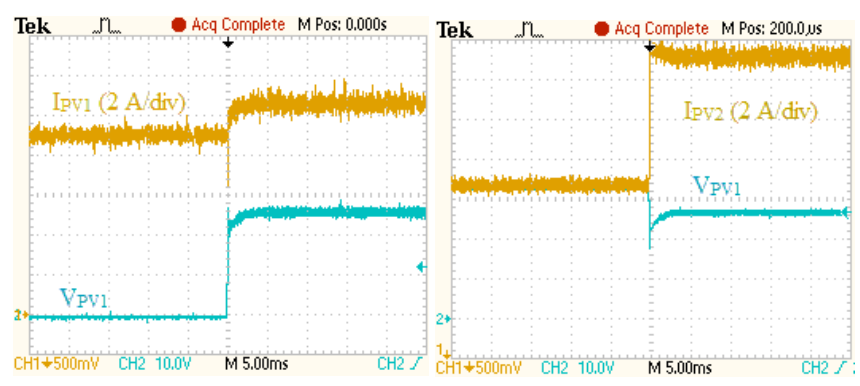

(a)

(b)

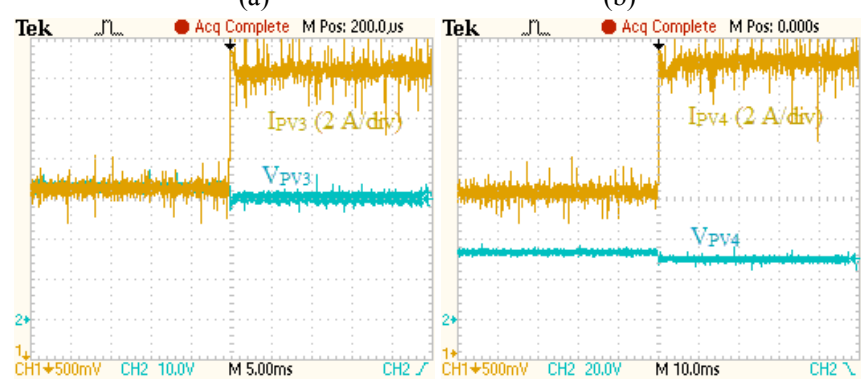

(c)

(d)

Fig. 21. Current and voltage during diverter turn on transient: a) PV1; b) PV2; c) PV3; c) PV4. 


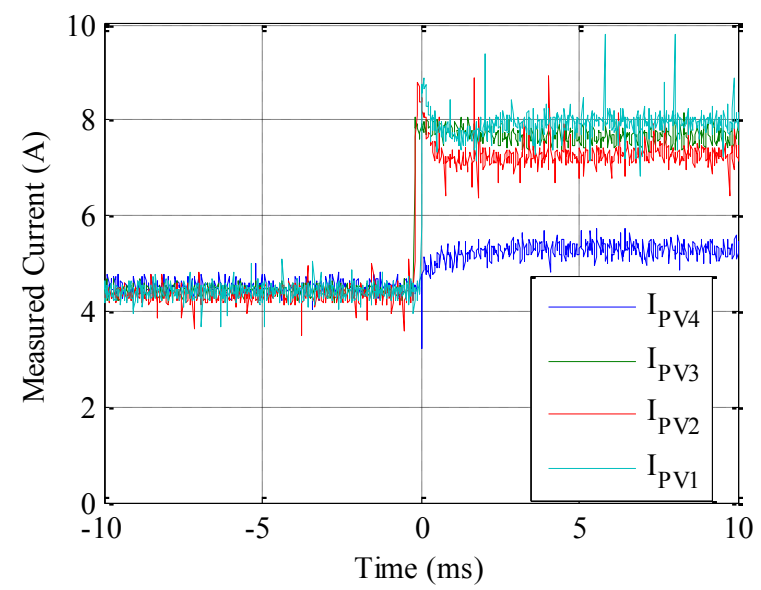

(a)

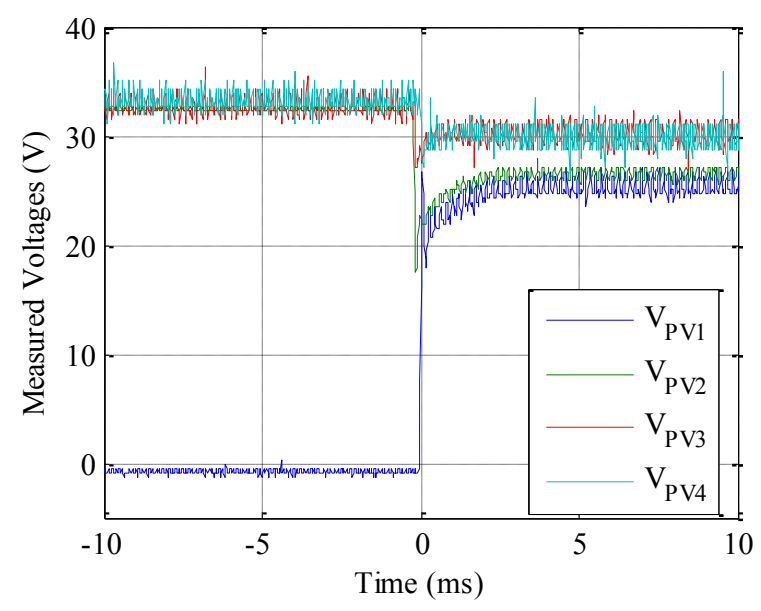

(b)

Fig. 22. Current and voltage of Figure 21 disposed in the same time window: (a) PV modules currents; (b) PV modules voltages.

diverter turn on, they begin to operate with different currents, and more power is generated. Regarding the voltage results, before the diverter operation, the PV1 voltage is below zero, because of its shaded condition, and after started, the diverter equalizes all modules voltages, despite the smaller difference between the first pair and the second one due winding resistance of diverter 02 inductor.

\section{CONCLUSION}

Partial shading has shown to be a problem of great concern in solar photovoltaic applications. Among the solutions, the switching diverter circuit enables an array of partially shaded modules to deliver maximum power, by the voltage equalization principle. Through simulation studies, a problem was found concerning the size of the inductor, and the increase of inductors current with string order. Also, this topology needs synchronous gate-drivers to operate. Therefore, a new topology, named CCSCD, was proposed. This circuit does not present deviated current accumulation like the NDSCD, and it is built with independent diverter cells. This fact facilitates the circuit design, since each diverter cell may have its own local oscillator for switching the circuit. Also, it allows an easy implementation of a local MPPT, by varying the voltage in each level, instead of equalizing. Simulation results show the advantages of switched deviation. However, the current accumulation problem is pointed out in the classical diverter, and eliminated in the proposed circuit. At last, a local MPPT was implemented in each diverter cell, by measuring its voltage and current outputs. This last result shown a small enhance of efficiency, using the local MPPT. Since the circuits are independent, they do not need synchronism, and each of them may have its voltage and current measuring, and the local MPPT can be implemented without communication between each cell. Thus, the CCSCD has potential to become a plug-and-play diverter for connection with various types of string inverters. Regarding the implementation for 3 or 6 panels strings, simulation and schematic examples were presented to clarify the modifications necessary for this type of circuits. Experimental results showing the proposed topology application confirmed many theoretical aspects studied in simulation. In these experiments, a string of four panels with adjustable orientation towards the sun was used to simulate, in practice, situations near to the partial shading. A CCSCD was built with three independent diverter cells, without any communication between them, and operating from 42 to $44 \mathrm{kHz}$. Operating with $50 \%$ fixed duty-cycle it allowed each panel to deliver its own current output by equalizing their voltages, with an expected low voltage ripple. Experimental results like: inductors currents and PV modules output current and voltage were presented to corroborate the theoretical development.

\section{ACKNOWLEDGEMENT}

The authors would like to acknowledge the financial support of FAPEMIG. We are very grateful for CEFET-MG for allowing the installation of the PV modules, and for the support of various other institutional members involved. Also, we grateful for the learning provided by the graduation program PPGEE of UFMG.

\section{REFERENCES}

[1] D. I. Brandão, F. P. Marafão, F. A. S. Gonçalves, Villalva, M. G., Gazoli, J. R., "Estratégia de Controle Multifuncional para Sistemas Fotovoltaicos de Geração de Energia Elétrica", Eletrônica de Potência, vol. 18, ${ }^{\circ}$ 4, pp. 1206-1214, sep./nov. 2013.

[2] J. G. Matos, L. A. S. Ribeiro, F. S. Freitas e Silva, "Controle da Potência Gerada em Microrredes Autônomas e Isoladas com Fontes de Energia Renováveis e Sistema de Armazenamento com Banco de Baterias", Eletrônica de Potência, vol. 19, n 2, pp.152162, march/may 2014.

[3] M. C. B. P. Rodrigues, J. G. Oliveira, A. A. Ferreira, P. G. Barbosa, H. A. C. Braga, "Conexão de Veículos Elétricos à Rede de Energia Elétrica Para Recarga de Baterias: Uma visão Geral”, Eletrônica de Potência, vol. 19, n 2, pp. 193-207, march/may 2014.

[4] W. W. A. G. Silva, P. F. Donoso-Garcia, S. I. Seleme Jr, T. R. Oliveira, C. H. G. Santos, A. S. Bolzon, "Study of the Application of Bidirectional Dual Active Bridge 
Converters in DC Nanogrid Energy Storage System" in Proc. of COBEP, vol. 14, pp. 609-614, 2014.

[5] A. F. B. Oliveira, S. M. Silva, C. H. G. Santos, B. J. Cardoso Filho, "Aplicação do Controle Repetitivo A Inversor PWM Monofásico com Filtro LC de Saída Utilizado em Fonte Programável c.a.”, Eletrônica de Potência, vol. 18, n 4, pp. 1161-1169, sep./nov. 2013.

[6] T. Kerekes, "Analysis and Modeling of transformeless Photovoltaic Inverter Systems". PhD Dissertation. Institute of Energy Technology, Aalborg University, Denmark, 2009.

[7] L. Linares, R. W. Erickson, S. MacAlpine, and M. Brandemuehl. "Improved Energy Capture in Series String Photovoltaics via Smart Distributed Power Electronics", in Proc. Of APEC, pp. 904-910, feb. 2009.

[8] NuVision Energy Solutions, Inc., "Sunpower Vs. Other Solar Panels with shading issues", disponível: www.youtube.com/watch?v=d_z9Ztrfoug.

[9] K. Ding, X. Wang, Q. X. Zhai, J. W. Xu, J. W. Zhang, and H. H. Liu, "Improved Global Maximum Power Point Tracking Method Based on Voltage Interval for PV Array under Partially Shaded Conditions", Journal of Power Electronics, vol. 14, n 4, pp. 722-732, July 2014.

[10] P. A. Sobreira Jr, F. L. Tofoli, H. A. C. Braga, P. G. Barbosa, A. A. Ferreira, “Analysis of MPPT Techniques to The DCM Multiphase Boost Converter for The Mitigation of Partial Shading in PV Arrays", Eletrônica de Potência, vol. 18, n.4, pp. 1138-1148, sep/nov 2013.

[11] R. Kadri, J. P. Gaubert, and G. Champenois. "Nondissipative String Current Diverter for Solving the Cascaded DC-DC Converter Connection Problem in Photovoltaic Power Generation System". IEEE Transactions on Power Electronics, vol. 27, $\mathrm{n}^{\circ} 3$, pp. 1249-1258, march 2012.

[12] R. Kadri, J. P. Gaubert, G. Champenois. "New Converter Topology to Improve Performance of Photovoltaic Power Generation System Under Shading Conditions", in Proc. of Power Engineering, Energy and Electrical Drives, pp. 1-7, may 2011.

[13] R. K. Hester, C. Thornton, S. Dhople, Z. Zhao, N. Sridhar, and D. Freeman, "High Efficiency Wide Load Range Buck/Boost/Bridge Photovoltaic Microconverter", in Proc. of APEC, pp. 309-313, 2011.

[14] W. Zhou and T. Phillips, "Industry's First 4-Switch Buck-Boost Controller Achieves Highest Efficiency Using a Single Inductor" - Design Note 369, Linear Technology.

[15] X. Ren, Z. Tang, X. Ruan, J. Wei, and G. Hua, "Four Switch Buck-Boost Converter for Telecom DC-DC Power Supply Applications", in Proc. of APEC, pp. 1527 - 1530, 2011.

[16] M. Orellana, S. Petibon, B. Estibals, C. Alonso, "Four Switch Buck-Boost Converter for Photovoltaic DC-DC
Power Applications", in Proc. IECON, pp. 469-474, 2010.

[17]N. Mohan, T. M. Undeland, W. P. Robbins, Power Electronics: converters, applications, and design, John Wiley \& Sons, $2^{a}$ Ed., NY, 1995.

\section{BIOGRAPHIES}

Cláudio Henrique Gomes Santos was born in October 05, 1982 in Divinópolis, MG - Brazil. Has received his M.Sc and B.Sc. degrees in Electrical Engineering from CEFETMG in Belo Horizonte, Brazil in 2008 and 2011, respectively.

Nowadays, he is a teacher member of de Mechatronics Engineer Department of CEFET-MG, located in St. Álvares Azevedo 400, in Divinópolis, Brazil. He also had same position in the Federal University of Outo Preto, MG Brazil. His currently research interest is power-qualityrelated issues, solar PV technology, switching power supplies and repetitive control. His previous interest was in EMC, antennas and FACTs applications.

Pedro Francisco Donoso-Garcia, has graduated in electrical engineering option in electronics by the Universidade Federal do Rio Grande do Sul - UFRGS in 1981, he received his MSc from the Universidade Federal de Minas Gerais - UFMG and his PhD in Electrical Engineering from the Universidade Federal de Santa Catarina - UFSC in 1986 and 1991 respectively. Currently he is an Associate Professor at the Electronic Engineering Dept.-DELTUFMG. His research interest include: high efficiency power supply, electronic ballasts and different microgrid aspects, including power electronics and distributed energy-storage systems.

Seleme Isaac Seleme Jr. was born in Novemeber 031955 in Palmas, PR - Brazil. Has graduated in Electrical Engineering from EPUSP at São Paulo in 1977, obtained his M.Sc from UFSC at Florianópolis, in 1985 and his $\mathrm{PhD}$ from INPG at Grenoble, France, in 1994. He has made his Post Doctorate at UC Berleley, USA, in 2002. Presently he is an Associate Professor, member of the Electronic Department at the Engineering School, UFMG. His main research interests are power electronics, applied control for static converters, electrical drive systems and electromechanical systems.

André Palhares de Magalhães, was born in August 23, 1988 in Patos de Minas, MG - Brazil. Nowadays, he is a undergraduate Mechatronics Engineering student of CEFETMG, located in St. Álvares Azevedo 400, in Divinópolis, Brazil. Currently his research interest is on solar PV technology, switching power supplies, solar tracking systems and grid-tied and isolated PV systems. 